\title{
Potential of $\left[{ }^{11} \mathrm{C}\right]$ acetate for measuring myocardial blood flow: Studies in normal subjects and patients with hypertrophic cardiomyopathy
}

\author{
S. A. J. Timmer, BSc, ${ }^{a}$ M. Lubberink, PhD, ${ }^{\mathrm{a}}$ T. Germans, MD, PhD, ${ }^{\mathrm{b}}$ M. J. W. Götte, \\ $M D, P h D, b$ J. M. ten Berg, MD, PhD, ${ }^{c}$ F. J. ten Cate, MD, PhD, ${ }^{\mathrm{d}}$ A. C. van Rossum, \\ $\mathrm{MD}, \mathrm{PhD},{ }^{\mathrm{b}}$ A. A. Lammertsma, $\mathrm{PhD},{ }^{\mathrm{a}}$ and P. Knaapen, $\mathrm{MD}, \mathrm{PhD}^{\mathrm{b}}$
}

Background. Measuring the rate of clearance of carbon-11 labelled acetate from myocardium using positron emission tomography (PET) is an accepted technique for noninvasively assessing myocardial oxygen consumption. Initial myocardial uptake of $\left[{ }^{11} \mathrm{C}\right]$ acetate, however, is related to myocardial blood flow (MBF) and several tracer kinetic models for quantifying MBF using [ $\left.{ }^{11} \mathrm{C}\right]$ acetate have been proposed. The objective of this study was to assess these models.

Methods. Eighteen healthy subjects and 18 patients with hypertrophic cardiomyopathy $(\mathrm{HCM})$ were studied under baseline conditions with $\left[{ }^{11} \mathrm{C}\right]$ acetate and $\left[{ }^{15} \mathrm{O}\right]$ water. Four previously reported methods, including single- and multi-tissue compartment models, were used to calculate MBF from the measured [ ${ }^{11} \mathrm{C}$ ]acetate rate of influx $K_{1}$ and the (previously) reported relationship between $K_{1}$ and MBF. These MBF values were then compared with those derived from corresponding $\left[{ }^{15}\right.$ O]water studies.

Results. For all models, correlations between $\left[{ }^{11} \mathrm{C}\right]$ acetate and $\left[{ }^{15} \mathrm{O}\right]$ water-derived $\mathrm{MBF}$ ranged from .67 to .86 (all $P<.005)$ in the control group and from .73 to .85 (all $P<.001$ ) in the HCM group. Two out of four models systematically underestimated perfusion with $\left[{ }^{11} \mathrm{C}\right]$ acetate, whilst the third model resulted in an overestimation. The fourth model, based on a simple single tissue compartment model with spillover, partial volume and recirculating metabolite corrections, resulted in a regression equation with a slope of near unity and an $Y$-intercept of almost zero (controls, $K_{1}=.74[\mathrm{MBF}]+.09, r=.86, \mathrm{SEE}=.13, P<.001$ and $\mathrm{HCM}$, $\left.K_{1}=.89[\mathrm{MBF}]+.03, r=.85, \mathrm{SEE}=.12, P<.001\right)$.

Conclusion. $\left[{ }^{11} \mathrm{C}\right]$ acetate enables quantification of $\mathrm{MBF}$ in fairly good agreement with actual MBF in both healthy individuals and patients with HCM. A single tissue compartment model with standardized correction for recirculating metabolites and with corrections for partial volume and spillover provided the best results. (J Nucl Cardiol 2010;17:264-75.)

Key Words: Myocardial blood flow $\cdot\left[{ }^{11} \mathrm{C}\right]$ acetate $\cdot\left[{ }^{15} \mathrm{O}\right]$ water $\cdot$ positron emission tomography $\cdot$ hypertrophic cardiomyopathy

From the Department of Nuclear Medicine \& PET Research, ${ }^{\text {a }}$ Department of Cardiology, ${ }^{\mathrm{b}}$ VU University Medical Centre, Amsterdam, The Netherlands; Department of Cardiology, ${ }^{c}$ St. Antonius Hospital, Nieuwegein, The Netherlands; Department of Cardiology, ${ }^{\mathrm{d}}$ Thorax Centre Erasmus Medical Centre, Rotterdam, The Netherlands.

Received for publication Aug 10, 2009; final revision accepted Dec 4, 2009.

Reprint requests: P. Knaapen, $\mathrm{MD}, \mathrm{PhD}$, Department of Cardiology, 5F, VU University Medical Centre, De Boelelaan 1117, 1081 HV, Amsterdam, The Netherlands; p.knaapen@vumc.nl. $1071-3581 / \$ 34.00$

Copyright $(2009$ by the American Society of Nuclear Cardiology. doi:10.1007/s12350-009-9181-y

\section{INTRODUCTION}

Carbon-11 labelled acetate is an established tracer for the non-invasive evaluation of myocardial oxygen consumption $\left(\mathrm{MVO}_{2}\right)$ with positron emission tomography (PET) ${ }^{1-5}$ Oxidative metabolism is related to the early rate of clearance of tracer in the myocardium, whereas initial tracer uptake is dependent on myocardial blood flow (MBF). Therefore, it is tempting to derive simultaneous information on $\mathrm{MBF}$ and $\mathrm{MVO}_{2}$ from a single dynamic cardiac $\left[{ }^{11} \mathrm{C}\right]$ acetate study, despite the fact that 
quantification of MBF from $\left[{ }^{11} \mathrm{C}\right]$ acetate data is hampered by incomplete extraction of the tracer, partial volume and spillover effects, and recirculation of ${ }^{11} \mathrm{C}$-labelled metabolites. Several strategies to (semi)quantify MBF using $\left[{ }^{11} \mathrm{C}\right]$ acetate have been proposed. Gropler et al were the first to demonstrate that initial myocardial uptake of $\left[{ }^{11} \mathrm{C}\right]$ acetate serves as an indirect measure of regional MBF. ${ }^{6}$ Subsequently, more complex tracer kinetic models with arterial blood sampling have been used, taking into account early $\left[{ }^{11} \mathrm{C}\right]$ acetate metabolism and applying corrections for spillover and partial volume effects. ${ }^{7,8}$ Others have developed somewhat simplified kinetic models using either an average metabolite correction ${ }^{9}$ or disregarding recirculating ${ }^{11} \mathrm{C}$-labelled metabolites altogether. ${ }^{6,10-12}$ Although all reported methods showed reasonable correlation with $\mathrm{MBF}$, it is as yet unclear which method provides the most accurate estimate of perfusion, as a direct comparison of the various methods is lacking. Furthermore, the validity of the different models in the presence of left ventricular (LV) hypertrophy requires additional investigation, as increased wall thickness and altered LV geometry affect partial volume effects, and thus perfusion estimates. Therefore, the objective of this study was to assess these models in both normal subjects and patients with hypertrophic cardiomyopathy (HCM) using a direct comparison with $\mathrm{MBF}$ as measured with oxygen-15 labelled water.

\section{MATERIALS AND METHODS}

\section{Subjects}

Eighteen healthy subjects without relevant medical history and with normal physical examination, electrocardiogram, and two-dimensional echocardiography, and 18 patients with HCM were included in the study. HCM was diagnosed according to the presence of a nondilated and hypertrophied LV on two-dimensional echocardiography (maximal wall thickness $>15 \mathrm{~mm}$ in adult index patients or $>13 \mathrm{~mm}$ in adult relatives of an HCM patient) in the absence of any other systemic or cardiac disease. ${ }^{13}$ All patients underwent coronary angiography to exclude the presence of coronary artery disease. The use of betablockers or calcium channel blockers was not discontinued during the study. All subjects gave written informed consent, and the protocol was approved by the Medical Ethics Review Committee of the VU University Medical Centre, Amsterdam, The Netherlands.

\section{PET Scanning Protocol}

All PET scans were acquired under resting conditions using an ECAT EXACT HR+ scanner (Siemens/CTI, Knoxville, TN) in two-dimensional mode. A transmission scan was performed using three rotating ${ }^{68} \mathrm{Ga} /{ }^{68} \mathrm{Ge}$ rod sources. Subsequently, $1100 \mathrm{MBq}{ }^{15} \mathrm{O}$-labelled water, dissolved in a $5 \mathrm{~mL}$ saline solution, was injected intravenously, followed by a
40-mL saline solution flush at a rate of $4 \mathrm{~mL} / \mathrm{second}$. A dynamic emission scan was acquired, consisting of 40 frames with variable frame length $(12 * 5,12 * 10,6 * 20$, and $10 * 30$ seconds) and with a total duration of 10 minutes. Emission data were corrected for physical decay of ${ }^{15} \mathrm{O}$, dead time, scatter, randoms and photon attenuation. After a period of about 10 minutes to allow for decay of $\left[{ }^{15} \mathrm{O}\right]$ water, $550 \mathrm{MBq}\left[{ }^{11} \mathrm{C}\right]$ acetate was injected intravenously. At the same time a dynamic emission scan was started, consisting of 29 frames $(12 * 10,3 * 20,4 * 60,3 * 120$, and $7 * 300$ seconds) and with a total duration of 48 minutes. During all studies the rate pressure product (RPP), being the product of systolic blood pressure and heart rate, was monitored.

\section{PET Data Analysis}

Data were transferred to a SUN workstation (SUN Microsystems Inc.) and analyzed using standard scanner software, together with additional tracer kinetic analysis software developed in MATLAB. $\left[{ }^{15} \mathrm{O}\right]$ water and $\left[{ }^{11} \mathrm{C}\right]$ acetate sinograms were reconstructed using filtered back projection with a Hanning filter at .5 of the Nyquist frequency, resulting in a transaxial spatial resolution of $\approx 7 \mathrm{~mm}$ full width at halfmaximum. Regions of interest (ROIs) were defined manually on $\left[{ }^{11} \mathrm{C}\right]$ acetate short axis summed uptake images at basal, midventricular and apical levels of the left ventricle, according to a 13-segment model as described previously. ${ }^{14}$ This set of ROIs was projected onto the dynamic $\left[{ }^{15} \mathrm{O}\right]$ water and $\left[{ }^{11} \mathrm{C}\right]$ acetate images to generate time activity curves (TACs). Figure 1 depicts a representative example of a myocardial $\left[{ }^{11} \mathrm{C}\right]$ acetate TAC. Additional ROIs were defined in left atrium and right ventricular chamber. This latter set of ROIs was also projected onto the dynamic $\left[{ }^{15} \mathrm{O}\right]$ water and $\left[{ }^{11} \mathrm{C}\right]$ acetate images to generate TACs of intravascular activity. These latter TACs were used as image derived input functions and for spillover correction of myocardial tissue TACs.

\section{Calculation of Myocardial Blood Flow}

Using the standard single tissue compartment model, MBF (mL/minute/g of perfusable tissue) was determined for all myocardial $\left[{ }^{15} \mathrm{O}\right]$ water TACs. ${ }^{15}$ Global MBF was calculated by grouping all ROIs, weighted for ROI volume. Corrections were performed for both left and right ventricular spillover effects, as described by Hermansen et al. ${ }^{16}$

For the determination of MBF from $\left[{ }^{11} \mathrm{C}\right]$ acetate data, four different tracer kinetic models were investigated, which all have been proposed and validated in humans previously. The design and results of these studies are summarized in Table 1 .

Because resting $\mathrm{MBF}$ is related to the RPP, corrected resting $\mathrm{MBF}\left(\mathrm{MBF}_{\text {corr }}\right)$, calculated as $(\mathrm{MBF} / \mathrm{RPP}) \times 10.000$, was also determined for both the $\left[{ }^{15} \mathrm{O}\right]$ water and $\left[{ }^{11} \mathrm{C}\right]$ acetate PET studies.

\section{Method 1}

Chan and co-workers related net myocardial uptake values of $\left[{ }^{11} \mathrm{C}\right]$ acetate to $\mathrm{MBF}$ measurements acquired with 


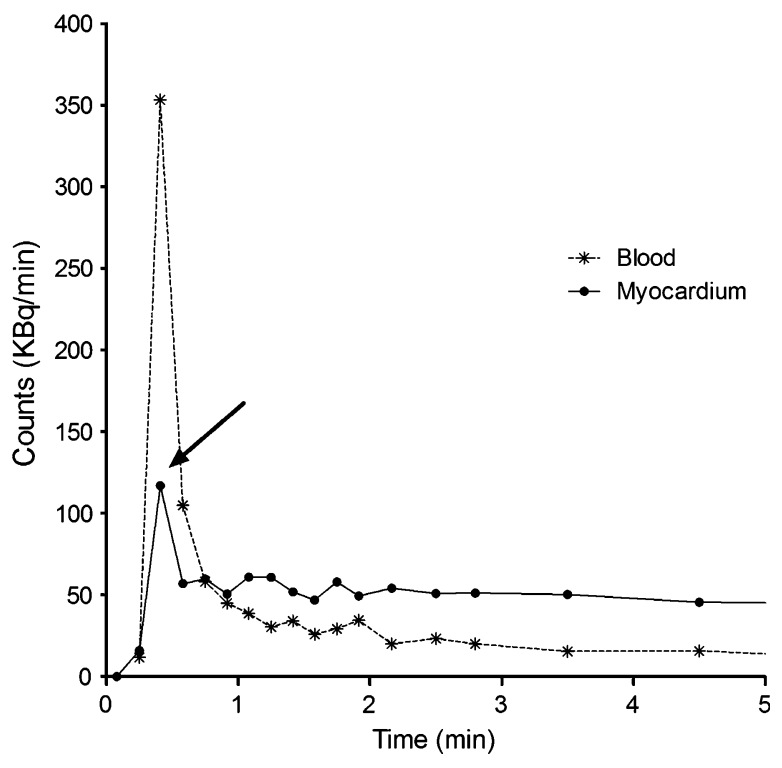

Figure 1. $\left[{ }^{11} \mathrm{C}\right]$ acetate time activity curves for a normal subject. Note the peak of myocardial activity, indicating a profound effect of spillover from blood to myocardium (indicated by the arrow).

$\left[{ }^{13} \mathrm{~N}\right]$ ammonia. ${ }^{10}$ This approach is comparable to the one proposed by Gropler et al. ${ }^{6}$ Net myocardial uptake of tracer was assessed by dividing total myocardial tissue concentration at 4 minutes after tracer injection, by the area under the arterial input curve over the first 4 minutes. The time point of 4 minutes was chosen, as the myocardial $\left[{ }^{11} \mathrm{C}\right]$ acetate concentration was highest, whereas the blood concentration was relatively low. No corrections for spillover, partial volume effects and labelled metabolites were made. The reported regression equation between $\left[{ }^{11} \mathrm{C}\right]$ acetate obtained $K_{1}$ values and $\left[{ }^{13} \mathrm{~N}\right]$ ammoniaderived perfusion was $K_{1}=.55 \times \mathrm{MBF}+.08$.

\section{Method 2}

A more complex two tissue compartment model for determining quantitative flow was proposed by Sun et al, ${ }^{8}$ as depicted in Figure 2A. Clearance of ${ }^{11} \mathrm{C}$ activity occurs from both tissue compartments by the efflux of ${ }^{11} \mathrm{CO}_{2}$. Arterial blood samples were taken to correct the arterial input function for recirculation-labelled metabolites. In addition, spillover corrections were included, and fixed partial volume corrections were applied assuming a uniform wall thickness of $1 \mathrm{~cm}$ in all subjects. Total scan time was 15 minutes. The reported regression equation between $\left[{ }^{11} \mathrm{C}\right]$ acetate obtained $K_{1}$ values and $\left[{ }^{13} \mathrm{~N}\right]$ ammonia-derived perfusion was $K_{1}=.726 \times$ $\mathrm{MBF}+.152$

\section{Method 3}

Sciacca et $\mathrm{al}^{11}$ proposed a modified two tissue compartment model for the assessment of $\mathrm{MBF}$ with $\left[{ }^{11} \mathrm{C}\right]$ acetate (Figure 2B). It was hypothesized that $\left[{ }^{11} \mathrm{C}\right]$ acetate, after being extracted from blood into myocardial tissue, is cleared as a function of blood flow and/or metabolism. Spillover corrections were included in the model, and fixed partial volume corrections were applied assuming a recovery coefficient of .65. The reported regression equation between $\left[{ }^{11} \mathrm{C}\right]$ acetate obtained $K_{1}$ values and $\left[{ }^{15} \mathrm{O}\right]$ water-derived perfusion was $K_{1}=1.057 \times \mathrm{MBF}+.27$.

\section{Method 4}

Recently, van den Hoff et al $^{9}$ proposed a simple single tissue compartment model for the assessment of net myocardial uptake with $\left[{ }^{11} \mathrm{C}\right]$ acetate (Figure 2C). This model combines myocardial efflux of ${ }^{11} \mathrm{CO}_{2}$ and other labelled metabolites clearance of $\left[{ }^{11} \mathrm{C}\right]$ acetate in a single-rate constant $\left(k_{2}\right)$. An average metabolite correction of the arterial input function was applied based on arterial blood sample data from Buck et $\mathrm{al}^{17}$ Data from the first 20 minutes after tracer injection were used to generate TACs. In addition, spillover and partial volume corrections were included in the model. The reported regression equation between $K_{1}$ values and $\left[{ }^{13} \mathrm{~N}\right]$ ammonia-derived perfusion was $K_{1}=1-.64 \mathrm{e}^{-1.2 / \mathrm{MBF}}$.

\section{Statistical Analysis}

Results are displayed as mean \pm standard deviation (SD). Differences in $\left[{ }^{15} \mathrm{O}\right]$ water-derived flow values between study groups were assessed by the unpaired Student's $t$ test. The significance of differences between $\left[{ }^{15} \mathrm{O}\right]$ water and $\left[{ }^{11} \mathrm{C}\right]$ acetate-derived estimates of MBF was assessed using the paired Student's $t$ test. Correlations between $\left[{ }^{15} \mathrm{O}\right]$ water and $\left[{ }^{11} \mathrm{C}\right]$ acetate derived estimates were evaluated using linear regression analysis. Bland-Altman (BA) plots were generated to evaluate methodological accuracy and to assess the limits of agreement. ${ }^{18}$ The repeatability coefficient $(\mathrm{RC})$ for the BA plots was calculated as 1.96 times the SD of the mean difference between the two methods. $P$ values $<.05$ were considered statistically significant.

\section{RESULTS}

Baseline characteristics of both study groups are presented in Table 2. No significant differences were present between the control and HCM group for sex, body surface area (BSA), LV end-diastolic volume (LVEDV), LV end-systolic volume (LVESV) and LV ejection fraction (LVEF), whereas age and LV mass (LVM) were significantly increased in patients with $\operatorname{HCM}(P=.01$ and $P<.001$, respectively). Nearly all HCM patients were using one or more drugs $(\mathrm{n}=15$ betablockers, $\mathrm{n}=6$ calcium channel blockers, $\mathrm{n}=5$ both).

\section{Myocardial Blood Flow Measurements Using $\left[{ }^{15}\right.$ O]Water}

MBF values derived from $\left[{ }^{15} \mathrm{O}\right]$ water scans averaged $.98 \pm .26 \mathrm{~mL} / \mathrm{minute} / \mathrm{g}$ for the entire study population (Table 3), with a range from .57 to $1.56 \mathrm{~mL} / \mathrm{minute} / \mathrm{g}$. 


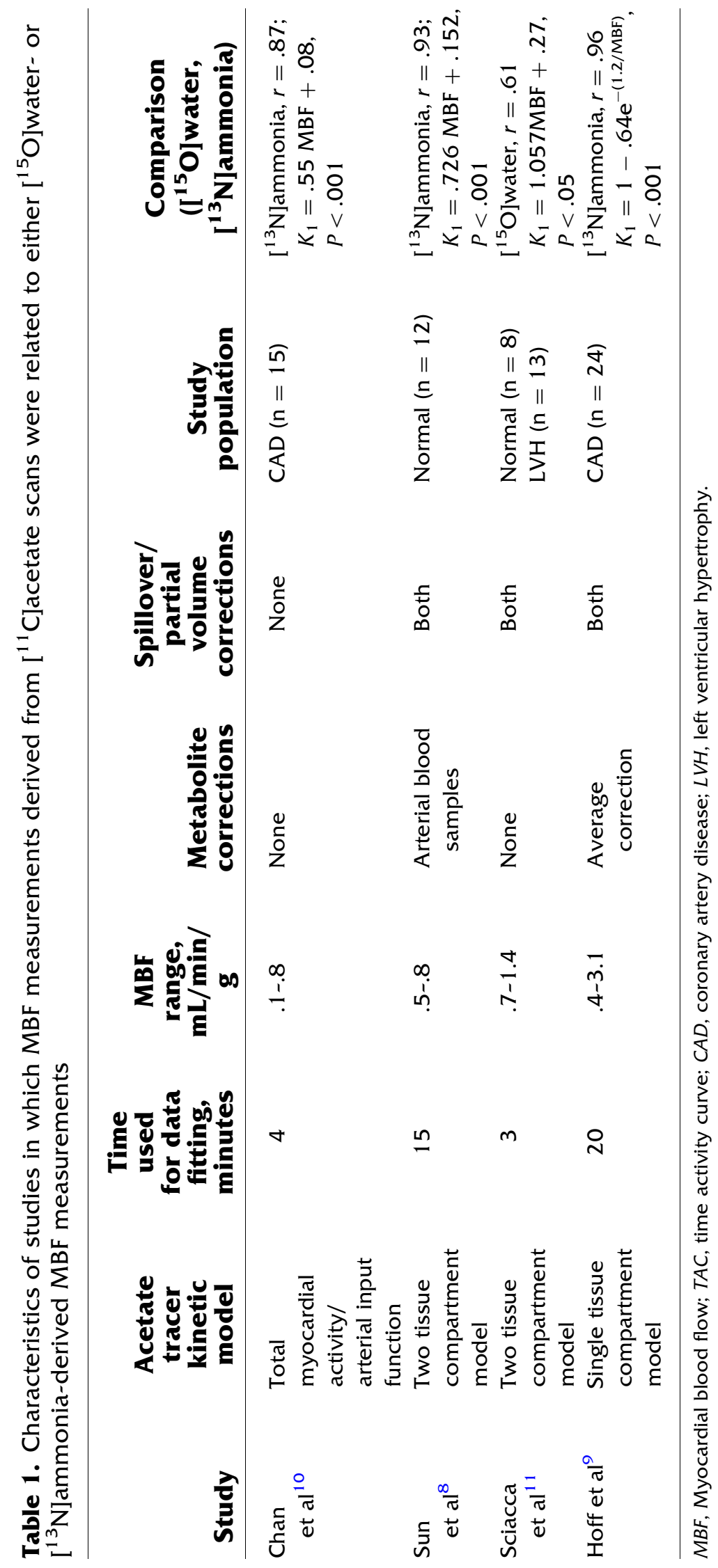


A

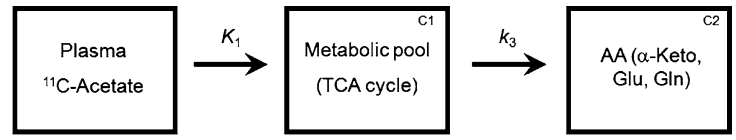

B

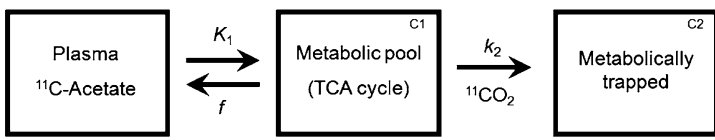

C

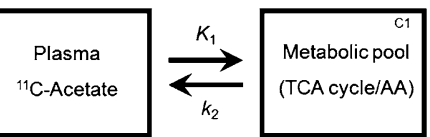

Figure 2. (A) Two tissue compartment model as proposed by Sun et al. ${ }^{8}$ In all models, $K_{1}$ represents the influx into compartment $1 . k_{2}$ represents the rate constant of clearance of $\mathrm{CO}_{2}$ from compartment 1 and reflects the oxidative flux through the tricarboxylic acid cycle. $k_{3}$ represents the rate constant of clearance of $\mathrm{CO}_{2}$ efflux from compartment 2. (B) Two tissue compartment model as proposed by Sciacca et al. ${ }^{11}$ $k_{2}$ represents the transformation of tracer to metabolic products which are trapped in compartment 2. Washout of tracer from compartment 1 to blood is depicted as a function of MBF $(f)$. (C) One tissue compartment model as proposed by van den Hoff et al. ${ }^{9} k_{2}$ represents the rate constant for tracer washout to blood and transferal of ${ }^{11} \mathrm{C}$ to metabolic products. TCA cycle, Tricarboxylic acid cycle; $A A$, amino acids; $\alpha$-Keto, $\alpha$-Ketoglutarate; Glu, Glutamate; Gln, Glutamine.

Table 2. Baseline characteristics

\begin{tabular}{llll}
\hline & $\begin{array}{c}\text { Controls } \\
(\mathbf{N}=\mathbf{1 8})\end{array}$ & $\begin{array}{c}\text { HCM } \\
(\mathbf{N}=\mathbf{1 8})\end{array}$ & $\boldsymbol{P}$ \\
\hline Sex & 8 men & 9 men & .85 \\
Age (year) & $44 \pm 15$ & $57 \pm 15$ & .01 \\
BSA (m $\left.{ }^{2}\right)$ & $2.0 \pm .2$ & $2.1 \pm .2$ & .72 \\
LVM $(\mathrm{g})$ & $94 \pm 20$ & $192 \pm 80$ & .001 \\
LVEDV $(\mathrm{mL})$ & $182 \pm 29$ & $188 \pm 32$ & .55 \\
LVESV $(\mathrm{mL})$ & $73 \pm 19$ & $74 \pm 21$ & .88 \\
LVEF $(\%)$ & $61 \pm 5$ & $60 \pm 7$ & .90 \\
\hline
\end{tabular}

$H C M$, Hypertrophic cardiomyopathy; $B S A$, body surface area; $L V M$, left ventricular mass; $L V E D V$, left ventricular end-diastolic volume; $L V E S V$, left ventricular end-systolic volume; $L V E F$, left ventricular ejection fraction.

Average MBF values were not significantly different between healthy individuals $(1.06 \pm .29 \mathrm{~mL} /$ minute $/ \mathrm{g})$ and patients with $\mathrm{HCM}(.90 \pm .21 \mathrm{~mL} /$ minute $/ \mathrm{g})$ $(P=.07)$. On average, the RPP between $\left[{ }^{15} \mathrm{O}\right]$ water (7911 $\mathrm{mmHg} /$ minute) and the $\left[{ }^{11} \mathrm{C}\right]$ acetate scans

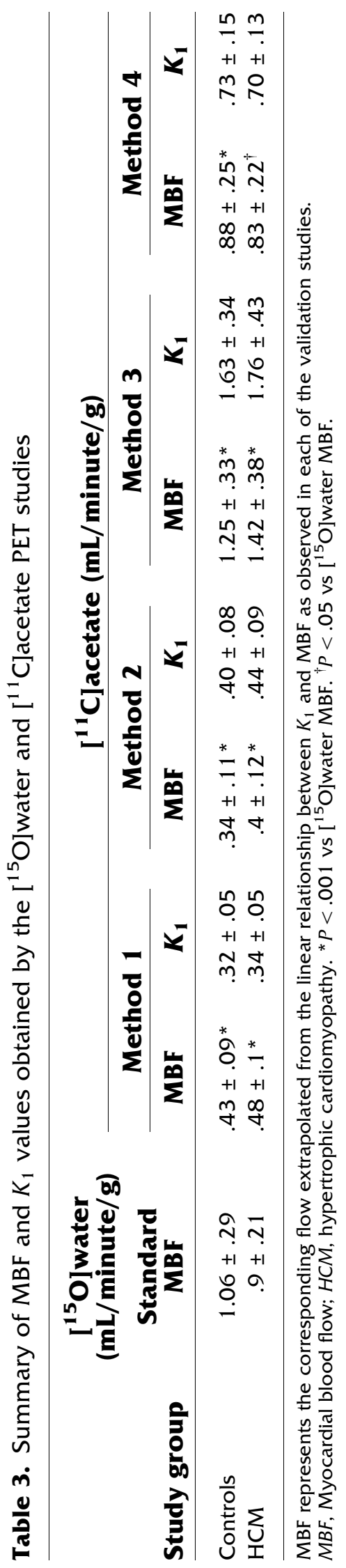


(7979 $\mathrm{mmHg} /$ minute $)$ was comparable $(P=.67)$, whereas the variation of the RPP between the successive scans was $2 \pm 8 \%$.

\section{Myocardial Blood Flow Measurements Using [ [ $\left.{ }^{11} \mathrm{C}\right]$ Acetate}

MBF was calculated from the $\left[{ }^{11} \mathrm{C}\right]$ acetate scans using the four methods described above. Results for both MBF and $K_{1}$ are given (Table 3), in addition to the differences between $\left[{ }^{15} \mathrm{O}\right]$ water and $\left[{ }^{11} \mathrm{C}\right]$ acetate obtained mean MBF (Table 4). $K_{1}$ represents net myocardial uptake of $\left[{ }^{11} \mathrm{C}\right]$ acetate, whilst $\mathrm{MBF}$ represents the corresponding flow value calculated using the relationship between $K_{1}$ and $\mathrm{MBF}$, as provided in each of the original validation studies.

\section{Method 1}

For Method 1, MBF obtained with $\left[{ }^{11} \mathrm{C}\right]$ acetate averaged $.43 \pm .09 \mathrm{~mL} / \mathrm{minute} / \mathrm{g}$ in the control group and $.48 \pm .1 \mathrm{~mL} / \mathrm{minute} / \mathrm{g}$ in the HCM group. The correlation coefficients between $\left[{ }^{15} \mathrm{O}\right]$ water and $\left[{ }^{11} \mathrm{C}\right]$ acetate-derived values were $r=.76$ and $r=.80$ in control and HCM groups, respectively (both $P<.001$ ). Corresponding regression plots are shown in Figure 3A. Bland-Altman analysis of $\mathrm{MBF}$ demonstrated a mean difference of $.53 \pm .22 \mathrm{~mL} / \mathrm{minute} / \mathrm{g}$ between $\left[{ }^{15} \mathrm{O}\right]$ water and $\left[{ }^{11} \mathrm{C}\right]$ acetate significantly different from zero $(P<.001)$ (Figure 3B), whilst the RC equalled .43. Figure 3C and D depicts the regression for $K_{1}$ values against MBF with the corresponding Bland-Altman plot. After correction for the RPP, the regression line and correlation coefficient between $\left[{ }^{15} \mathrm{O}\right]$ water and $\left[{ }^{11} \mathrm{C}\right]$ acetate $\mathrm{MBF}_{\text {corr }}$ were $y=.197 x+.20, r=.70$ for the control group and $y=.318 x+.09, r=.78$ for the HCM group (both $P<.001)$.

\section{Method 2}

For Method 2, MBF obtained with $\left[{ }^{11} \mathrm{C}\right]$ acetate averaged $.34 \pm .11 \mathrm{~mL} / \mathrm{minute} / \mathrm{g}$ in the control group and $.40 \pm .12 \mathrm{~mL} / \mathrm{minute} / \mathrm{g}$ in the $\mathrm{HCM}$ group. The correlation coefficients between $\left[{ }^{15} \mathrm{O}\right]$ water and $\left[{ }^{11} \mathrm{C}\right]$ acetate derived values were $r=.85$ for both control and HCM groups (both $P<.001$ ). Corresponding regression plots are shown in Figure 4A. Bland-Altman analysis of MBF (Figure 4B) demonstrated a mean difference of $.61 \pm .20 \mathrm{~mL} /$ minute/g between $\left[{ }^{15} \mathrm{O}\right]$ water and $\left[{ }^{11} \mathrm{C}\right]$ acetate derived $\mathrm{MBF}$ values significantly different from zero $(P<.001)$, whilst the RC equalled .41 . Figure $4 \mathrm{C}$ and $\mathrm{D}$ depicts the regression for $K_{1}$ against $\mathrm{MBF}$ with the corresponding Bland-Altman plot. The regression line and correlation coefficient between $\left[{ }^{15} \mathrm{O}\right]$ water and $\left[{ }^{11} \mathrm{C}\right]$ acetate $\mathrm{MBF}_{\text {corr }}$ were $y=.251 x+$ $.16, r=.82$ for the control group and $y=.446 x+.01$, $r=.82$ for the HCM group (both $P<.001$ ).

\section{Method 3}

The results from Method 3 showed an average MBF obtained with [ ${ }^{11} \mathrm{C}$ ]acetate of $1.25 \pm .33 \mathrm{~mL} / \mathrm{minute} / \mathrm{g}$ in the control group and $1.42 \pm .38 \mathrm{~mL} / \mathrm{minute} / \mathrm{g}$ in the HCM group. The correlation coefficients between $\left[{ }^{15} \mathrm{O}\right]$ water and $\left[{ }^{11} \mathrm{C}\right]$ acetate derived values were $r=.67$ and $r=.73$ in control and HCM groups, respectively (both $P<.005$ ). Corresponding regression plots are shown in Figure 5A. Bland-Altman analysis of $\mathrm{MBF}$ (Figure 5B) demonstrated a mean difference of $-.29 \pm$ $.26 \mathrm{~mL} / \mathrm{minute} / \mathrm{g}$ between $\left[{ }^{15} \mathrm{O}\right]$ water and $\left[{ }^{11} \mathrm{C}\right]$ acetate derived $\mathrm{MBF}$ values significantly different from zero $(P<.001)$, whilst the RC equalled .59. Figure 5C and D depicts the regression between $K_{1}$ and $\mathrm{MBF}$ with the corresponding Bland-Altman plot. The regression line and correlation coefficient between $\left[{ }^{15} \mathrm{O}\right]$ water and $\left[{ }^{11} \mathrm{C}\right]$ acetate $\mathrm{MBF}_{\text {corr }}$ were $y=.843 x+.51, r=.66$ for the control group and $y=1.532 x+.09, r=.77$ for the HCM group (both $P<.001$ ).

\section{Method 4}

Using Method 4, $\left[{ }^{11} \mathrm{C}\right]$ acetate-derived MBF values averaged $.88 \pm .25 \mathrm{~mL} / \mathrm{minute} / \mathrm{g}$ in the control group and $.83 \pm .22 \mathrm{~mL} / \mathrm{minute} / \mathrm{g}$ in the $\mathrm{HCM}$ group. The correlation coefficients between $\left[{ }^{15} \mathrm{O}\right]$ water and $\left[{ }^{11} \mathrm{C}\right]$ acetate derived values were $r=.86$ and $r=.85$ in

Table 4. Differences between mean $\left[{ }^{15} \mathrm{O}\right]$ water and $\left[{ }^{11} \mathrm{C}\right]$ acetate obtained MBF values

\begin{tabular}{|c|c|c|c|c|}
\hline \multirow[b]{2}{*}{ Study group } & \multicolumn{4}{|c|}{$\left[{ }^{15}\right.$ O]water MBF $-\left[{ }^{11} \mathrm{C}\right]$ acetate $\mathrm{MBF}$} \\
\hline & Method 1 & Method 2 & Method 3 & Method 4 \\
\hline Controls & $.63 \pm .23$ & $.72 \pm .21$ & $-.22 \pm .25$ & $.18 \pm .15$ \\
\hline $\mathrm{HCM}$ & $.43 \pm .14$ & $.51 \pm .12$ & $-.51 \pm .30$ & $.07 \pm .12$ \\
\hline
\end{tabular}

$M B F$, Myocardial blood flow; $H C M$, hypertrophic cardiomyopathy. 

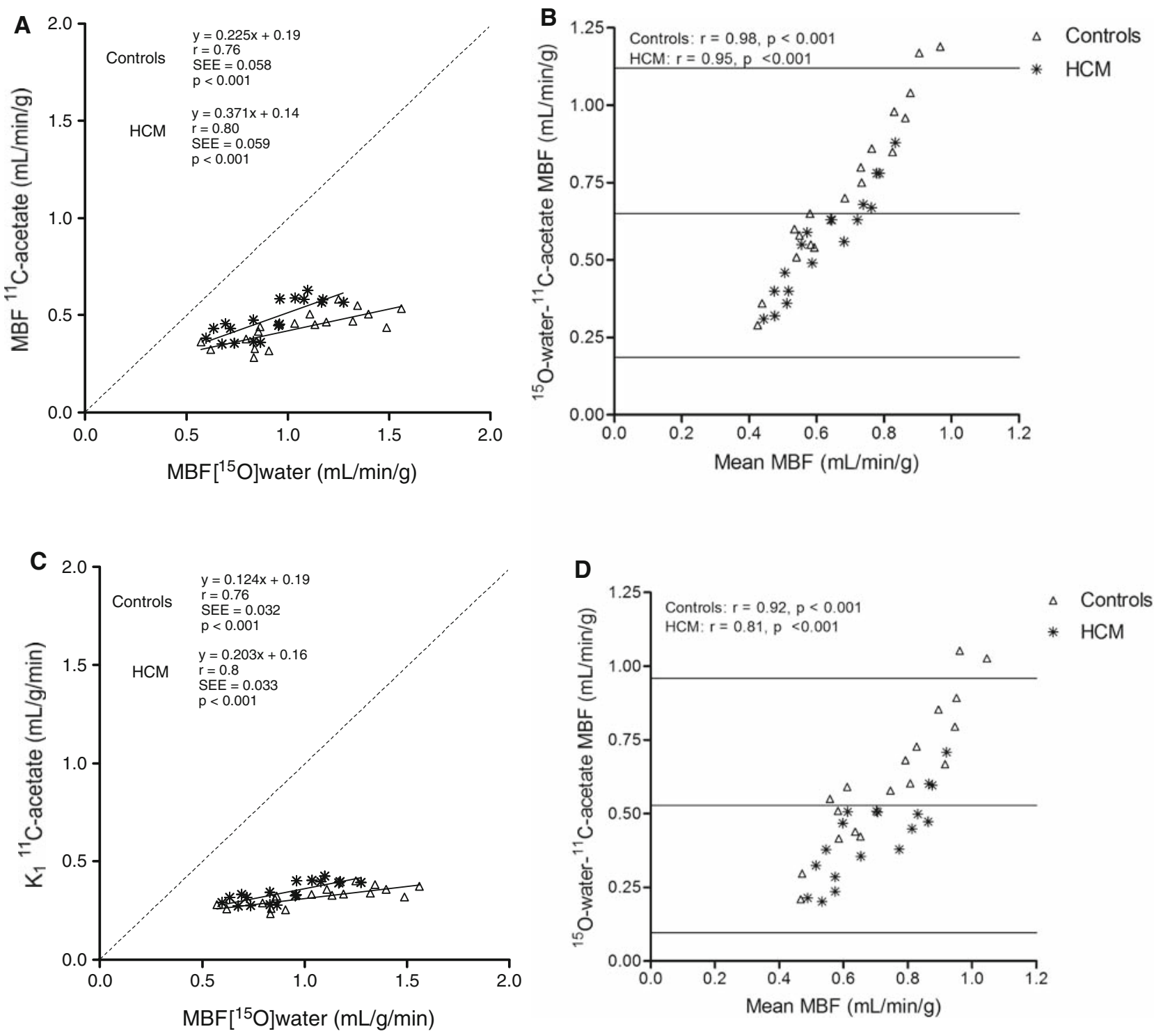

Figure 3. (A) Regression analysis and (B) corresponding Bland-Altman plot for MBF derived from $\left[{ }^{11} \mathrm{C}\right]$ acetate against MBF derived from $\left[{ }^{15} \mathrm{O}\right]$ water for Method 1. (C) Regression analysis, and (D) corresponding Bland-Altman plot for $K_{1}$ values obtained from $\left[{ }^{11} \mathrm{C}\right]$ acetate against $\mathrm{MBF}$ derived from $\left[{ }^{15} \mathrm{O}\right]$ water. The horizontal solid lines in the Bland-Altman plots represent mean differences and $95 \%$ confidence limits $( \pm 2$ SD). Note the significant trend of progressively increasing differences as a function of increasing MBF. TAC, Time activity curve; HCM, hypertrophic cardiomyopathy.

control and HCM groups, respectively (both $P<.001$ ). Corresponding regression plots are shown in Figure 6A. Bland-Altman analysis of MBF (Figure 6B) demonstrated a mean difference $.13 \pm .14 \mathrm{~mL} /$ minute $/ \mathrm{g}$ between $\left[{ }^{15} \mathrm{O}\right]$ water and $\left[{ }^{11} \mathrm{C}\right]$ acetate derived MBF values significantly different from zero $(P<.001)$, whilst the $\mathrm{RC}$ equalled .29. Figure $6 \mathrm{C}$ and $\mathrm{D}$ depicts the regression between $K_{1}$ and $\mathrm{MBF}$ with the corresponding Bland-Altman plot. The regression line and correlation coefficient between $\left[{ }^{15} \mathrm{O}\right]$ water and $\left[{ }^{11} \mathrm{C}\right]$ acetate
$\mathrm{MBF}_{\text {corr }}$ were $y=.761 x+.10, r=.84$ for the control group and $y=.866 x+.03, r=.85$ for the HCM group (both $P<.001$ ).

\section{DISCUSSION}

This study was performed to evaluate different methods for quantifying MBF using $\left[{ }^{11} \mathrm{C}\right]$ acetate. To this end, paired $\left[{ }^{15} \mathrm{O}\right]$ water and $\left[{ }^{11} \mathrm{C}\right]$ acetate studies were performed in both healthy subjects and patients with 

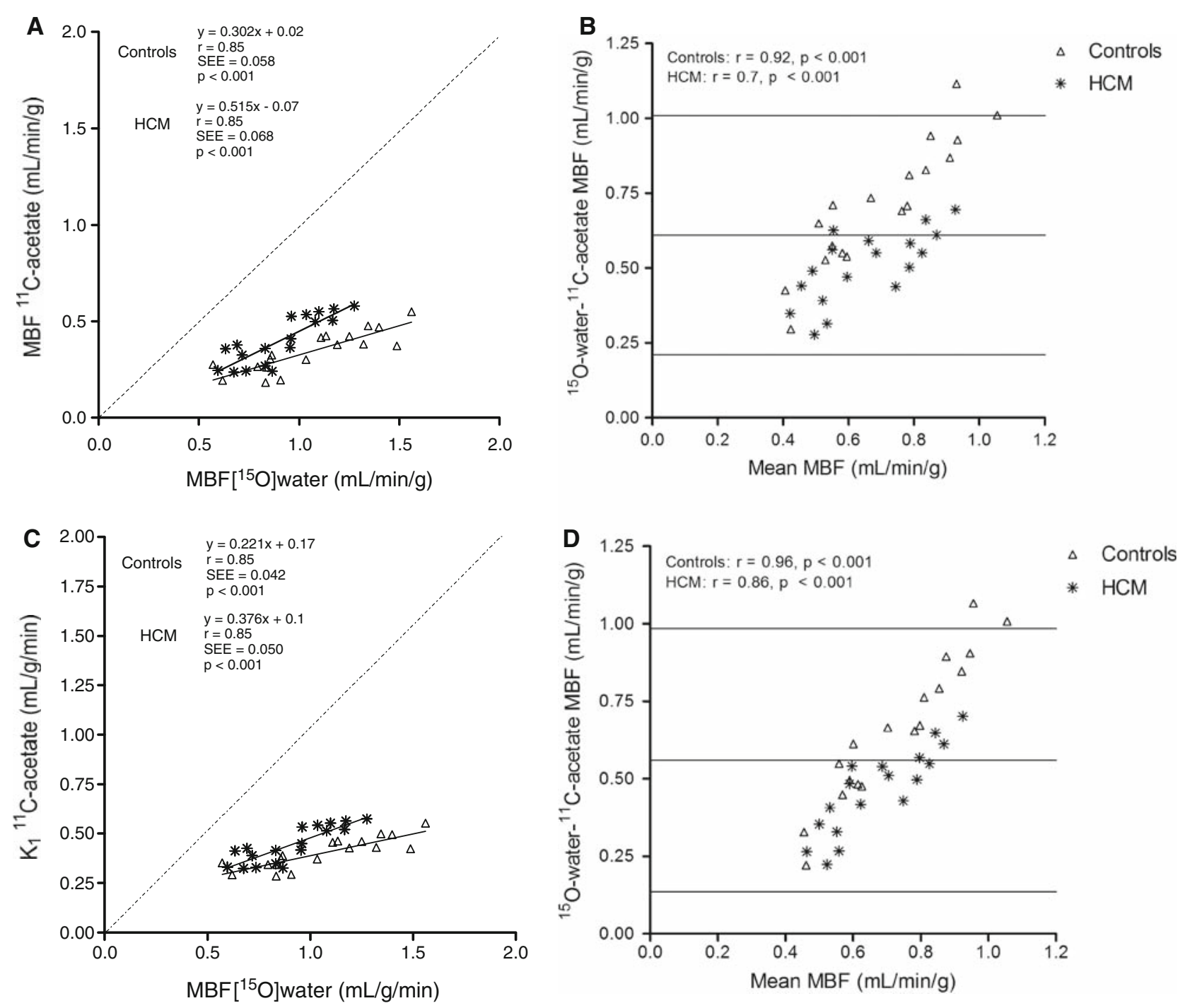

Figure 4. (A) Regression analysis and (B) corresponding Bland-Altman plot for MBF derived from $\left[{ }^{11} \mathrm{C}\right]$ acetate against MBF derived from $\left[{ }^{15} \mathrm{O}\right]$ water for Method 2. Note the linear relationship with equally strong correlation coefficients between both parameters over flow ranges from .5 to $1.5 \mathrm{~mL} / \mathrm{minute} / \mathrm{g}$ in both study groups. (C) Regression analysis and (D) corresponding BlandAltman plot for $K_{1}$ values obtained from $\left[{ }^{11} \mathrm{C}\right]$ acetate against $\mathrm{MBF}$ derived from $\left[{ }^{15} \mathrm{O}\right]$ water. The horizontal solid lines in the Bland-Altman plots represent mean differences and $95 \%$ confidence limits ( $\pm 2 \mathrm{SD})$. Note the significant trend of progressively increasing differences as a function of increasing MBF. TAC, Time activity curve; $H C M$, hypertrophic cardiomyopathy.

HCM. Amongst the four methods evaluated, the most accurate $\left[{ }^{11} \mathrm{C}\right]$ acetate-derived $\mathrm{MBF}$ values were obtained using a single tissue compartment model with standard correction for circulating labelled metabolites, together with partial volume and spillover corrections as described by van den Hoff et al (Method 4). MBF values obtained with this method showed strong correlations with $\left[{ }^{15} \mathrm{O}\right]$ water-derived MBF values in both control and HCM groups (Figure 6A) with a slope near unity and an $Y$-intercept close to zero. On average, the RPP did not significantly differ between the successive scans, whereas the regression lines and correlation coefficients between $\left[{ }^{15} \mathrm{O}\right]$ water and $\left[{ }^{11} \mathrm{C}\right]$ acetate $\mathrm{MBF}$ after correction for the RPP were generally comparable, both indicating stable hemodynamic conditions. These results confirm the potential value of $\left[{ }^{11} \mathrm{C}\right]$ acetate as a quantitative PET perfusion tracer.

Despite the fact that all four investigated methods displayed moderate-to-strong correlations in both study groups, it should be noted that for the other three methods, the slopes of the regression lines deviated from unity and/or $Y$-intercepts were different from zero. 

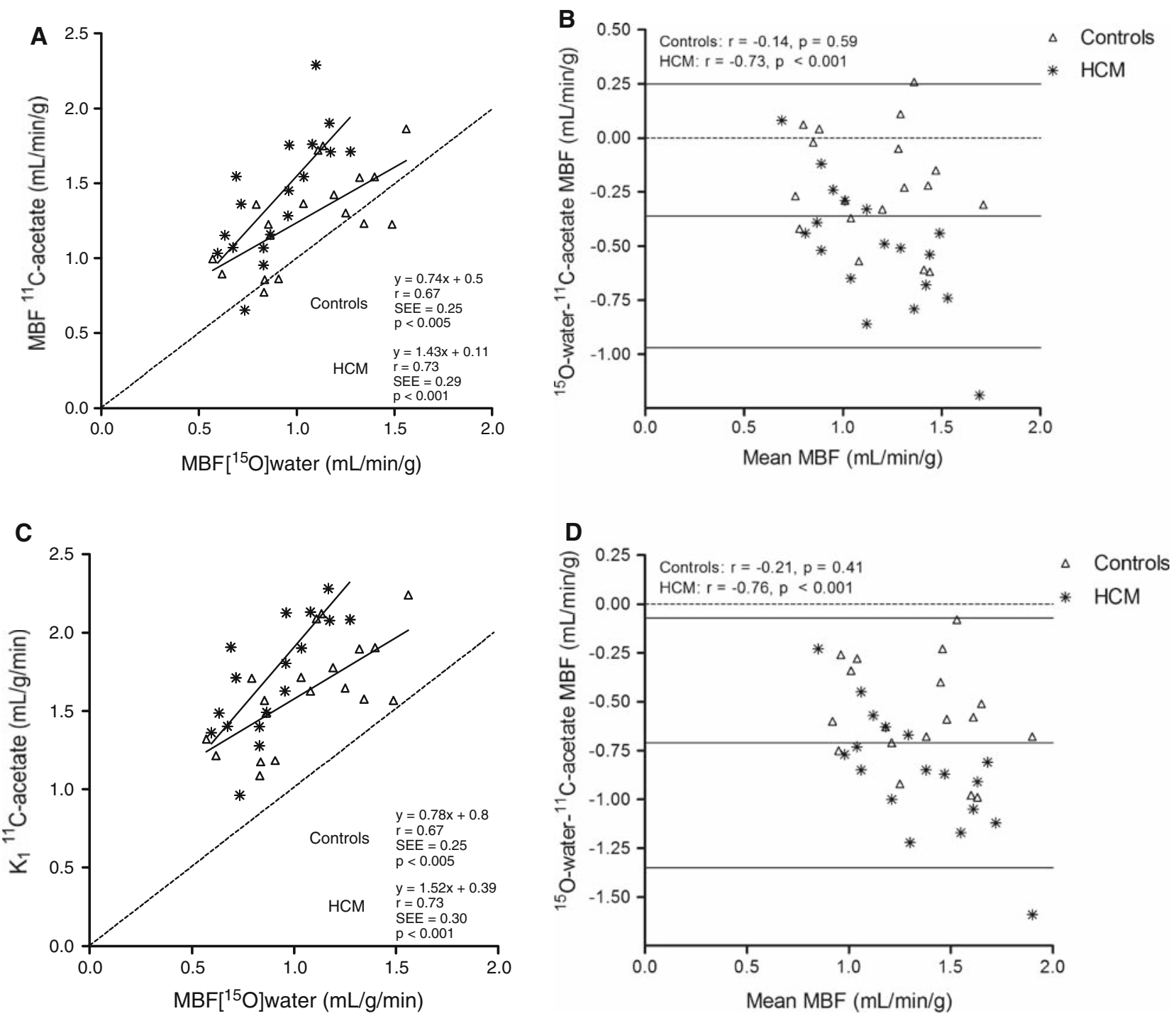

Figure 5. (A) Regression analysis and (B) corresponding Bland-Altman plot for MBF derived from $\left[{ }^{11} \mathrm{C}\right]$ acetate against MBF derived from $\left[{ }^{15} \mathrm{O}\right]$ water for method 3. (C) Regression analysis and (D) corresponding Bland-Altman plot for $K_{1}$ values obtained from $\left[{ }^{11} \mathrm{C}\right]$ acetate against $\mathrm{MBF}$ derived from $\left[{ }^{15} \mathrm{O}\right]$ water. The dashed lines represent zero difference, whereas mean differences and $95 \%$ confidence limits $( \pm 2 \mathrm{SD})$ are represented by the horizontal solid lines. TAC, Time activity curve; $H C M$, hypertrophic cardiomyopathy.

These results can for the large part be attributed to the following factors. First, based on previous investigations, ${ }^{19}$ Methods 1 and 3 assume that release of ${ }^{11} \mathrm{C}$ labelled metabolites, such as amino acids, TCA cycle intermediates and ${ }^{11} \mathrm{CO}_{2}$, during the initial myocardial uptake phase is minimal. However, it has been shown that, within the first 2 and 4 minutes, nearly $14 \%$ and $42 \%$ of radioactivity, respectively, can be ascribed to ${ }^{11} \mathrm{C}$-labelled metabolites. ${ }^{8}$ These labelled metabolites in arterial blood are mainly produced and released by noncardiac tissue. The contribution of these radioactive metabolites to total blood ${ }^{11} \mathrm{C}$ activity will result in an overestimation of the arterial input with subsequent underestimation of actual myocardial net tracer uptake. Second, several studies have shown that myocardial extraction of $\left[{ }^{11} \mathrm{C}\right]$ acetate is incomplete, decreasing with increasing myocardial perfusion. ${ }^{8,9,19}$ Recent data suggest that the extraction fraction of $\left[{ }^{11} \mathrm{C}\right]$ acetate ranges from $90 \%$ to $80 \%$ within the flow range of $.5-1.0 \mathrm{~mL} /$ minute/g. ${ }^{8,9}$ Therefore, $K_{1}$, being the product of flow and extraction fraction, will always be lower than MBF. Despite the fact that Methods 1-3 correct for incomplete extraction of $\left[{ }^{11} \mathrm{C}\right]$ acetate based on empirically obtained relationships between actual perfusion and $K_{1}$, they assume this relation to be linear. However, it is well known that extraction fraction itself is a function of flow 

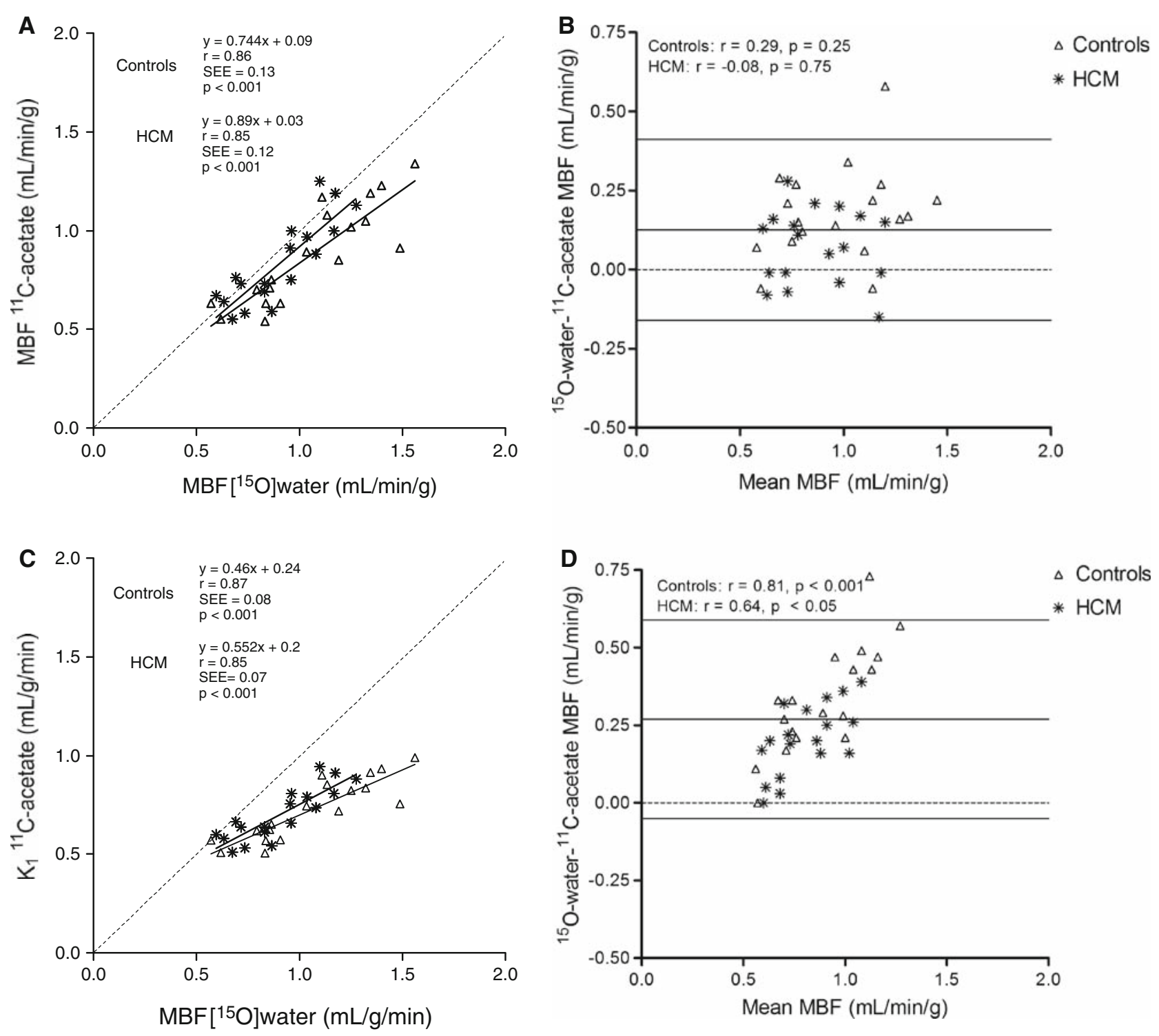

Figure 6. (A) Regression analysis and (B) corresponding Bland-Altman plot for MBF derived from $\left[{ }^{11} \mathrm{C}\right]$ acetate against MBF derived from $\left[{ }^{15} \mathrm{O}\right]$ water for Method 4. Note the linear relationship with strong correlation coefficients between both parameters over flow ranges from .5 to $1.5 \mathrm{~mL} / \mathrm{minute} / \mathrm{g}$ in both study groups. (C) Regression analysis, and (D) corresponding Bland-Altman plot for $K_{1}$ values obtained from $\left[{ }^{11} \mathrm{C}\right]$ acetate against MBF derived from $\left[{ }^{15} \mathrm{O}\right]$ water. The dashed lines represent zero difference, whereas mean differences and $95 \%$ confidence limits $( \pm 2 \mathrm{SD})$ are represented by the horizontal solid lines. TAC, Time activity curve; HCM, hypertrophic cardiomyopathy.

and, consequently, the relationship between $K_{1}$ and MBF is non-linear, as clearly demonstrated by van den Hoff et $\mathrm{al}^{9}$ Therefore, it can be postulated that describing the exponential relationship, between $\left[{ }^{11} \mathrm{C}\right]$ acetate extraction and flow, in a linear fashion, could result in less accurate flow estimations, where overestimation occurs within the lower flow range and underestimation can be observed within the higher flow ranges. It needs to be emphasized, however, that the use of an exponential function to describe the relationship between $K_{1}$ and MBF (Method 4), did not increase the accuracy of MBF estimates with $\left[{ }^{11} \mathrm{C}\right]$ acetate in the control group $\left(K_{1}\right.$ vs $\left[{ }^{15} \mathrm{O}\right]$ water $\mathrm{MBF}, r=.87$ and $\left[{ }^{11} \mathrm{C}\right]$ acetate $\mathrm{MBF}$ vs $\left[{ }^{15} \mathrm{O}\right]$ water MBF, $\left.r=.86\right)$, or the HCM group $\left(K_{1}\right.$ vs $\left[{ }^{15} \mathrm{O}\right]$ water MBF, $r=.85$ and $\left[{ }^{11} \mathrm{C}\right]$ acetate $\mathrm{MBF}$ vs $\left[{ }^{15} \mathrm{O}\right]$ water MBF, $r=.85$ ). Although the introduction of parameter estimation bias therefore seems limited when studies are performed under baseline conditions, 
correction for $\left[{ }^{11} \mathrm{C}\right]$ acetate extraction in a non-linear fashion seems warranted in the higher flow ranges to avoid underestimation of perfusion, in analogy to other similar PET perfusion tracers such as $\left[{ }^{13} \mathrm{~N}\right] \mathrm{ammonia}^{9}$ and $\left[{ }^{82} \mathrm{Rb}\right] .{ }^{20}$

For Methods 1-3, average $\left[{ }^{11} \mathrm{C}\right]$ acetate-derived $K_{1}$ and MBF values were consistently higher for the HCM group as compared with the control group, contrary to results obtained with $\left[{ }^{15} \mathrm{O}\right]$ water. This finding might be due to a number of factors. First, employing an average metabolite correction may improve the accuracy of arterial input functions, but it inherently assumes that $\left[{ }^{11} \mathrm{C}\right]$ acetate metabolism is not affected by myocardial pathology. Sun et al have shown that inter-individual differences in $\left[{ }^{11} \mathrm{C}\right]$ acetate metabolism are relatively small (range of $10-15 \%$ ) in healthy subjects, which is a prerequisite for the implementation of an average metabolite correction formula. ${ }^{8}$ Whether this assumption holds true for patients with HCM, however, is unclear. Second, an altered myocardial metabolic state due to myocardial pathology may result in a change in extraction fraction of $\left[{ }^{11} \mathrm{C}\right]$ acetate and consequently an altered relationship between $K_{1}$ and $\mathrm{MBF}^{21}$ Finally, whereas tracer kinetics of $\left[{ }^{15} \mathrm{O}\right]$ water allow for an accurate model-based correction of partial volume effects, ${ }^{15}$ the tracer kinetics of $\left[{ }^{11} \mathrm{C}\right]$ acetate do not. Since myocardial wall thickness is a determinant of partial volume effects, patients with $\mathrm{HCM}$ generally show higher measured myocardial $\left[{ }^{11} \mathrm{C}\right]$ acetate concentrations than healthy individuals. Therefore, the difference in average $\left[{ }^{11} \mathrm{C}\right]$ acetate-derived $\mathrm{MBF}$ values between control and HCM study groups could also be explained by higher measured $\left[{ }^{11} \mathrm{C}\right]$ acetate concentrations due to increased myocardial mass in the latter group.

Several additional remarks can be made considering the results obtained with the four methods investigated. Using Method 1, Chan and colleagues reported strong correlations $(r=.87, P<.001)$ between $\left[{ }^{11} \mathrm{C}\right]$ acetatederived $K_{1}$ values and $\left[{ }^{13} \mathrm{~N}\right]$ ammonia-derived $\mathrm{MBF}$ values. The present results, however, showed moderate correlation coefficients in both study groups, together with a large systematic underestimation of actual perfusion values. However, no corrections for spillover from myocardium to blood were applied. As depicted in Figure 1, at 4 minutes after tracer injection, total myocardial $\left[{ }^{11} \mathrm{C}\right]$ activity is substantially higher than in arterial blood, and myocardium to blood spillover would lead to an overestimation of the arterial input. In addition, early myocardial release of ${ }^{11} \mathrm{CO}_{2}$ at 4 minutes will result in underestimation of true myocardial tracer uptake. ${ }^{5,19}$ Therefore, according to this method, net myocardial uptake of $\left[{ }^{11} \mathrm{C}\right]$ acetate is increasingly underestimated with increasing myocardial perfusion.
Using Method 2, Sun et al report a strong correlation $(r=.93, P<.001)$ between $\left[{ }^{11} \mathrm{C}\right]$ acetate-derived $K_{1}$ values and $\left[{ }^{13} \mathrm{~N}\right]$ ammonia-derived MBF values. ${ }^{8}$ The correlation coefficient for this study was only marginally weaker. Nevertheless, the regression line describing the relationship between $\left[{ }^{11} \mathrm{C}\right]$ acetate and $\left[{ }^{15} \mathrm{O}\right]$ water obtained MBF (Controls, $y=.302 x+.02$ and HCM, $y=.515 x-.07)$ demonstrates large systematic underestimation of actual MBF values. Although the cause for the discrepancy remains to be elucidated, the relationship between $K_{1}$ and MBF found in the study population of Sun et al could not be reproduced in this study population. Differences in patient characteristics may have contributed to these observations and warrants further investigation.

Method 3 resulted in moderate correlation coefficients in both study groups (controls, $r=.73$ and HCM, $r=.67$ ), whereas the slope of the regression line (controls, $y=.74 x+.5$ and HCM, $1.43 x+.11$ ) showed substantial overestimation of actual perfusion values. This observation could be attributed to the fixed recovery coefficient of .65 , a correction for partial volume effects that is inaccurate with changes in myocardial thickness. Furthermore, the present tracer kinetic model is only applicable to fit data from the initial 3 minutes after tracer injection, thereby possibly limiting the statistical accuracy of MBF estimations.

Employing Method 4 yielded strong correlations with $\left[{ }^{15} \mathrm{O}\right]$ water-derived MBF in both control and HCM groups ( $r=.86$ and $r=.85$ ), although they were weaker than reported by van den Hoff et al $(r=.96) .{ }^{9}$ For both study groups, the regression line between $\left[{ }^{11} \mathrm{C}\right]$ acetate- and $\left[{ }^{15} \mathrm{O}\right]$ water-derived $\mathrm{MBF}$ values had a slope of almost unity and an $Y$-intercept close to zero, whereas Bland-Altman analysis showed a small systematic underestimation. In addition, this method was the only one that measured a lower mean MBF in the HCM group than in the healthy control group. These results suggest that the assessment of MBF using $\left[{ }^{11} \mathrm{C}\right]$ acetate is in fairly good agreement with actual perfusion, and of the models investigated that of van den Hoff et al yields the most accurate estimates. ${ }^{9}$

The high agreement between $\left[{ }^{11} \mathrm{C}\right]$ acetate- and $\left[{ }^{15} \mathrm{O}\right]$ water-obtained MBF introduces the possibility of a dual tracer research protocol in which resting MBF and $\mathrm{MVO}_{2}$ can be acquired simultaneously in a single dynamic $\left[{ }^{11} \mathrm{C}\right]$ acetate PET scan, whereas an additional $\left[{ }^{15} \mathrm{O}\right]$ water scan during maximal vasodilatation could provide with the flow reserve. However, the reproducibility of this approach in repeated investigations, i.e. test-retest variability, needs to be assessed in future studies. 


\section{Study Limitations}

The range of MBF values in this study was relatively narrow and obtained under baseline conditions only. Additional studies under a wider range of myocardial flow conditions (i.e., induced by beta-blockers, dipyridamole, or dobutamine) are needed to investigate the consistency, as well as intra- and interobserver reproducibility of $\mathrm{MBF}$ quantification with $\left[{ }^{11} \mathrm{C}\right]$ acetate PET. Due to the apparent nonlinear relationship between $\mathrm{K}_{1}$ and $\mathrm{MBF}$, these studies are especially important for hyperemic flow values. Furthermore, additional $\left[{ }^{15} \mathrm{O}\right]$ water PET data on hyperemic flow values would enable the calculation of the myocardial flow reserve with a hybrid tracer approach, i.e., the ratio between $\left[{ }^{15} \mathrm{O}\right]$ water hyperemic and $\left[{ }^{11} \mathrm{C}\right]$ acetate resting flow, in direct comparison to the standardized single tracer approach, i.e., $\left[{ }^{15} \mathrm{O}\right]$ water only. Finally, in this study, healthy control subjects and patients with HCM were investigated. Consequently, use of $\left[{ }^{11} \mathrm{C}\right]$ acetate to measure MBF in patients with other myocardial pathologies, such as coronary artery disease, should first be evaluated.

\section{CONCLUSION}

$\left[{ }^{11} \mathrm{C}\right]$ acetate enables quantification of MBF in fairly good agreement with actual perfusion values in both healthy individuals and patients with HCM over physiological flow ranges under baseline conditions. Of the investigated methodologies, the use of a single compartment model with a standardized recirculating metabolite, as well as partial volume and spillover corrections most accurately reflects $\mathrm{MBF}$ as measured with $\left[{ }^{15} \mathrm{O}\right]$ water.

\section{References}

1. Armbrecht JJ, Buxton DB, Brunken RC, Phelps ME, Schelbert HR. Regional myocardial oxygen consumption determined noninvasively in humans with [1-11C]acetate and dynamic positron tomography. Circulation 1989;80:863-72.

2. Klein LJ, Visser FC, Knaapen P, et al. Carbon-11 acetate as a tracer of myocardial oxygen consumption. Eur J Nucl Med 2001;28:651-68.

3. Knaapen P, Germans T, Knuuti J, et al. Myocardial energetics and efficiency: Current status of the noninvasive approach. Circulation 2007;115:918-27.

4. Buxton DB, Nienaber CA, Luxen A, et al. Noninvasive quantitation of regional myocardial oxygen consumption in vivo with [1-11C]acetate and dynamic positron emission tomography. Circulation 1989;79:134-42.

5. Brown MA, Myears DW, Bergmann SR. Validity of estimates of myocardial oxidative metabolism with carbon-11 acetate and positron emission tomography despite altered patterns of substrate utilization. J Nucl Med 1989;30:187-93.

6. Gropler RJ, Siegel BA, Geltman EM. Myocardial uptake of carbon-11-acetate as an indirect estimate of regional myocardial blood flow. J Nucl Med 1991;32:245-51.

7. Herrero P, Kim J, Sharp TL, et al. Assessment of myocardial blood flow using 15O-water and 1-11C-acetate in rats with small-animal PET. J Nucl Med 2006;47:477-85.

8. Sun KT, Yeatman LA, Buxton DB, et al. Simultaneous measurement of myocardial oxygen consumption and blood flow using [1-carbon-11]acetate. J Nucl Med 1998;39:272-80.

9. van den Hoff J, Burchert W, Borner AR, et al. [1-(11)C]Acetate as a quantitative perfusion tracer in myocardial PET. J Nucl Med 2001;42:1174-82.

10. Chan SY, Brunken RC, Phelps ME, Schelbert HR. Use of the metabolic tracer carbon-11-acetate for evaluation of regional myocardial perfusion. J Nucl Med 1991;32:665-72.

11. Sciacca RR, Akinboboye O, Chou RL, Epstein S, Bergmann SR. Measurement of myocardial blood flow with PET using 1-11Cacetate. J Nucl Med 2001;42:63-70.

12. Porenta G, Cherry S, Czernin J, et al. Noninvasive determination of myocardial blood flow, oxygen consumption and efficiency in normal humans by carbon-11 acetate positron emission tomography imaging. Eur J Nucl Med 1999;26:1465-74.

13. Knaapen P, Germans T, Camici PG, et al. Determinants of coronary microvascular dysfunction in symptomatic hypertrophic cardiomyopathy. Am J Physiol Heart Circ Physiol 2008; 294:H986-93

14. Knaapen P, Boellaard R, Gotte MJ, et al. Perfusable tissue index as a potential marker of fibrosis in patients with idiopathic dilated cardiomyopathy. J Nucl Med 2004;45:1299-304.

15. Iida H, Kanno I, Takahashi A, et al. Measurement of absolute myocardial blood flow with $\mathrm{H} 215 \mathrm{O}$ and dynamic positron-emission tomography. Strategy for quantification in relation to the partial-volume effect. Circulation 1988;78:104-15.

16. Hermansen F, Rosen SD, Fath-Ordoubadi F, et al. Measurement of myocardial blood flow with oxygen-15 labelled water: Comparison of different administration protocols. Eur J Nucl Med 1998;25:751-9.

17. Buck A, Wolpers HG, Hutchins GD, et al. Effect of carbon-11acetate recirculation on estimates of myocardial oxygen consumption by PET. J Nucl Med 1991;32:1950-7.

18. Bland JM, Altman DG. Statistical methods for assessing agreement between two methods of clinical measurement. Lancet 1986;1:307-10.

19. Armbrecht JJ, Buxton DB, Schelbert HR. Validation of [1-11C]acetate as a tracer for noninvasive assessment of oxidative metabolism with positron emission tomography in normal, ischemic, postischemic, and hyperemic canine myocardium. Circulation 1990;81:1594-605.

20. El Fakhri G, Kardan A, Sitek A, Dorbala S, Abi-Hatem N, Lahoud $\mathrm{Y}$, et al. Reproducibility and accuracy of quantitative myocardial blood flow assessment with ${ }^{82} \mathrm{Rb}$ PET: Comparison with ${ }^{13} \mathrm{~N}$-ammonia. J Nucl Med 2009;50:1062-71.

21. Cannon RO III, Rosing DR, Maron BJ, et al. Myocardial ischemia in patients with hypertrophic cardiomyopathy: Contribution of inadequate vasodilator reserve and elevated left ventricular filling pressures. Circulation 1985;71:234-43. 